\title{
The importance of a people-centred approach for Corporate Social Responsibility: A case study of Welverdiend and the surrounding community
}

\author{
VBESTER ${ }^{1} \&$ F CRONJÉ
}

\begin{abstract}
Despite the contribution of mining to the South African economy, this industry has impacted negatively on the environment and society for many decades. These negative impacts are mostly evidence of poor corporate actions. Instead of contributing to society, it seems that mining companies, more often than not, neglect their corporate social responsibilities (CSR) mostly in the pursuit of financial profit. It has been well documented that it is mostly local populations, living close to mining operations, that pay the price of social and environmental damages and degradation, while the industry's benefits are measured in economic and political terms. Such an imbalance between the economic, environmental and social factors makes Sustainable Development impossible to achieve.

Welverdiend, on the Far West Rand of Johannesburg, South Africa, is a community paying a dear price in terms of social problems caused by mining operations. The aim of this study was to assess the impact of mining on the social wellbeing of Welverdiend and the surrounding community's residents. In the light of these findings on different social issues, the research aimed to confirm the importance of a people-centred approach to Corporate Social Responsibility.
\end{abstract}

Keywords: Corporate Social Responsibility (CSR), economical contributions, environmental impacts, people-centred approach, social impacts, Social Licence to Operate (SLO), Sustainable Development (SD), Welverdiend

\section{Inroduction}

The Gold Reef, discovered by George Harrison in 1886 on the farm Langlaagte on the Witwatersrand, changed South Africa for ever. In this regard, Callinicos (2007:199) states that the discovery of gold transformed the country and became a ruler of South Africa's economy for decades to come.

However, despite the economic contributions of mining, this industry has impacted on the environment and society over many decades. In accordance with this, Warhust (1998:3) is of the opinion that although mining companies have positively contributed to social development, they have also been associated with some negative impacts, for example, deepening disparities in wealth, creating poor labour conditions, participating in corruption, polluting, failing both health and safety standards and disrespecting human rights.

These negative impacts are, in most instances, evidence of poor corporate actions. Instead of

1. Ms Vidette Bester holds a Masters degree in CSR from the North-West University. Email: videtteb@gmail.com

2. Prof. Freek Cronjé is the Director of the Bench Mark Centre for CSR at the Potchefstroom Campus of the North-West University. Email: freek.cronje@nwu.ac.za 
contributing to society, it seems that mining companies, more often than not, are escaping their corporate social responsibilities (CSR). Kapelus (2002:275) rightly remarks that these companies have long had a dubious reputation of mostly neglecting their social responsibility in the pursuit of economic development. With regard to this, Middleton (2003:331) states that a problem might occur when those who benefit from mining do not coincide with those who pay the cost of it. Banks (1993), cited in Middleton (2003:331), is of the opinion that those who pay the price in terms of social and environmental damage and degradation are mostly local populations, living in proximity to mining operations, while the industry's benefits are measured in economic and political terms.

The urgency for responsible and ethical business actions, where the economy is not favoured over society and the environment, brings the issue of Corporate Social Responsibility (CSR) strongly to the fore. A variety of definitions of CSR exists within its field. The European Commission (2002:3) defines CSR in a consised but striking way as a concept whereby companies voluntarily incorporate social and environmental concerns into their business operations and transactions with their stakeholders.

Three key concepts can be identified in this definition, namely: social, environmental and economical. Of course, these concepts also form the basis of sustainability and when viewed in this light, CSR and sustainability go hand in hand. Companies that adhere to sound CSR practices will most probably augment the whole question of sustainability, whilst sustainable development, on the other hand, will inevitably reflect sound CSR practices in terms of the social, environmental and economical dimensions.

The now classic definition of the concept of Sustainable Development (SD) is found in the 1987 Report of the World Commission on Environment and Development (WCED), named "Our Common Future". The WCED defined SD as follows: "Sustainable development is development which meets the needs of the present without compromising the ability of future generations to meet their own needs" (WCED, 1987:41). Blowfield and Murray (2008:27) state that this ability to sustain a high quality of life for current and future generations underlines the importance of companies rethinking what they produce and how they do so.

The above-mentioned conceptualisation of CSR and SD reiterates the reciprocal relationship that exists between these two concepts. In summary, Blowfield and Murray (2008:231) explain that sustainability issues lie at the theoretical heart of CSR; in addition, the International Institute for Sustainable Development (ISSD, 2010) confirms that CSR is an evolution in the approach to sustainable development. In order to achieve sound CSR practices and to create a sustainable milieu, the article argues that a human or people-centred approach must be the underlying approach of any company that operates in the vicinity of local communities.

Seeing that the Far West Rand has been greatly impacted upon by mining activities, the researchers identified the town of Welverdiend on the Far West Rand and the surrounding community to reflect on the CSR practices of mining companies.

The following section serves as an overview on Welverdiend and the surrounding community. 


\section{Background and orientation}

Gold mining activities in the Witwatersrand area initially started in 1886 (Naicker et al., 2002; Winde \& Stoch, 2010). The mining area known as the Witwatersrand was home to a vast number of mines extracting, among others, gold and uranium. Today only a few of those mines are still in operation. However, the Witwatersrand is still being regarded as the world's largest mining basin (Liefferink, 2009).

After mining commenced in 1886, gold mining extended to $30 \mathrm{~km}$ west of Johannesburg; this newly established gold field became known as the "West Rand". Attempts to move mining activities further to the south of the West Rand initially failed due to large volumes of water that flooded the newly sunken shafts (Winde \& Stoch, 2010). As stated by Winde and Stoch (2010), it was only in 1934 that new cementation technology allowed mines to sink shafts through water-bearing dolomite. Together with this new technology and the riches of a new gold field, an area known as the Far West Rand was recognised.

Welverdiend, a town that is part of the Far West Rand of South Africa, was founded in 1838 when settlers from the Cape Colony, who were farmers, migrated up to what was named the Mooi River and Wonderfonteinspruit area, of which Welverdiend and the surrounding farms are a part (Van Eeden, 2006:413) and agriculture was the initial primary economic activity in this region (Van Eeden, 2006:413).

In 1899 a railway running from Johannesburg to Cape Town passed through Welverdiend. Consequently businesses and infrastructure developed. In 1899 a station and Post Office were built, subsequently activity in Welverdiend became central by the access to the newly built infrastructure (Mr Stoch, 2014, pers.comm, May).

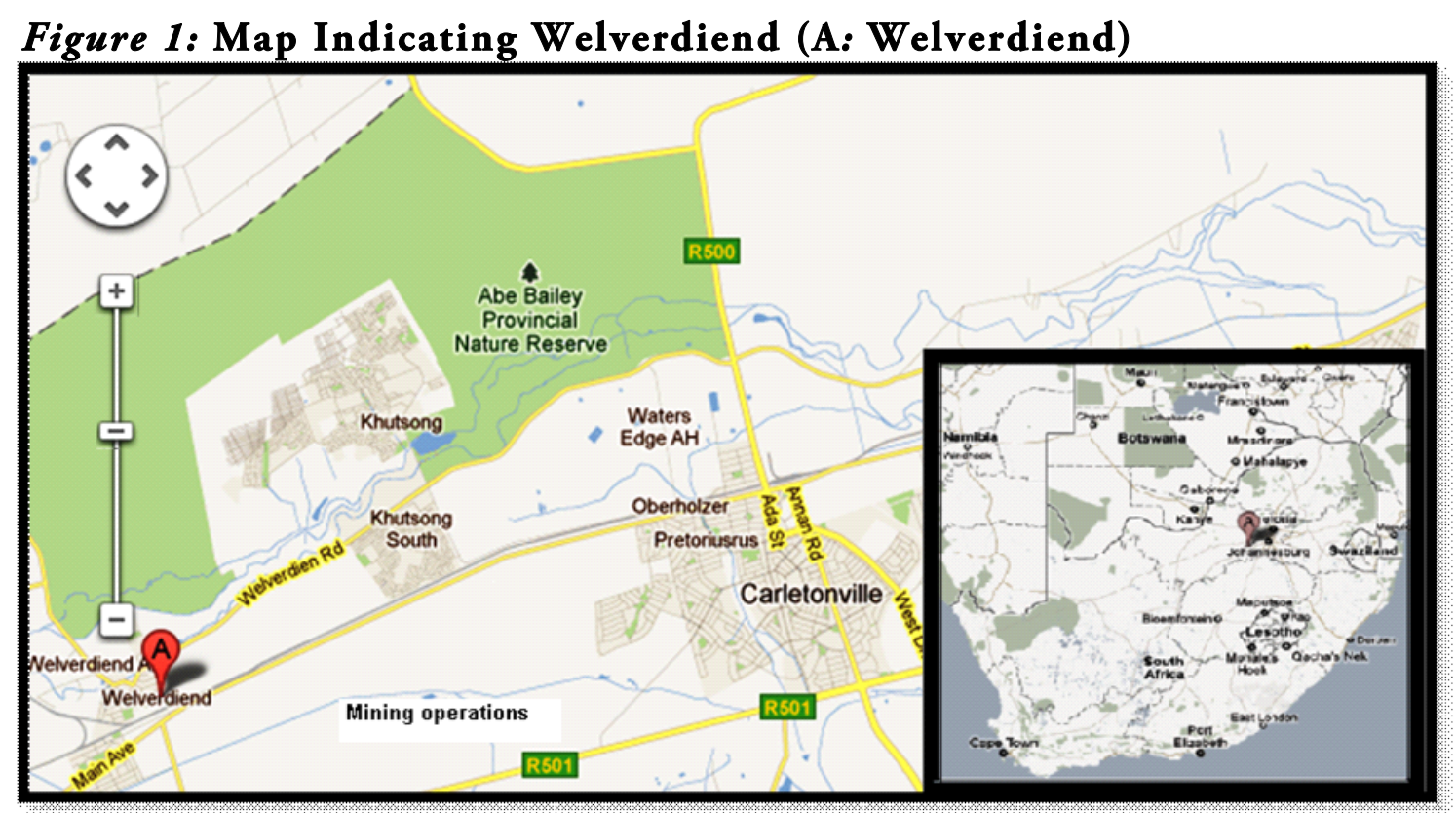

(Source: C2011 Google - Map data @2011 AfriGIS (Pty) Ltd Google)

The first mines to operate in the Far West Rand were Blyvooruitzicht and West Driefontein. Both these mines enjoyed wealth and prosperity in their operating days, and were renowned for their gold mine riches (Winde \& Stoch, 2010). Welverdiend housed workers from nearby mine Blyvooruitzicht whilst the mining village West Driefontein was built in 1937. 
Taken from the above-mentioned, Welverdiend consequently developed from agricultural activities and infrastructure, thus dividing the community of Welverdiend in two; those who practiced agriculture, being severely impacted by the regional mines, and those who worked for the mine and benefited from the mining activities (Mr Stoch, 2014, pers.comm, May).

Since the very start of the mining industry in this region, environmental as well as social issues arose; however, some attention was given to environmental problems by focusing on the conservation of the environment (see Bezuidenhout et al., 2007). The social problems were, however, ignored or kept from the public (see Van Eeden, 2006:427). However, later on, some historical social issues were documented.

Seeing that environmental and social issues are inseparable, a list of historical environmental aspects that occurred due to mining in the Far West Rand will be presented briefly:

- The formation of sinkholes since the mid-1950s because of dewatering activities by the mines (Swart et al., 2003:751; Van Niekerk \& Van der Walt, 2006:442; Coetzee et al., 2006:iii; Van Eeden et al., 2008:41; Van Eeden et al., 2009:53);

- Since the 1960s, the filling of sinkholes with contaminated slime, thus posing serious human and animal health risks (Coetzee et al., 2006:30; Van Eeden et al., 2008:46);

- The decline of farming activities in favour of mining activities since the 1960s, which resulted in a loss of livelihood (Van Eeden, 2006:421; Van Eeden, 2007:59; Van Eeden et al., 2008:45; Coetzee et al., 2006:iii);

- The discovery of high levels of radioactivity from as early as the 1970s (Van Eeden, 2006:424-27);

- The pollution of ground and surface water since the mid-20 ${ }^{\text {th }}$ century (Van Eeden, 2006:424-27; Winde \& Stoch, 2010:72); and

- The decrease in water levels since the early $20^{\text {th }}$ century (Van Eeden, 2008:470).

Seeing that mining activities have had a profound environmental impact on the Far West Rand, it is most probably likely that they have also had a social impact, leaving the town of Welverdiend and the surrounding community affected by them. In terms of social impact, the mining industry has, most probably, affected the welfare of the residents of Welverdiend and the surrounding community, making sustainable development hard to achieve.

\section{Research objectives}

Based on the above background, the objectives of this research article are divided into general and specific objectives and are as follows:

\subsection{General Objective}

This study aims to determine the social problems faced by the residents of Welverdiend and the surrounding community in order to reflect on the importance of sound CSR actions, and, more importantly, to confirm the importance of a people-centred approach to CSR.

\subsection{Specific Objectives}

The following specific research objectives have been identified: 
1. To put forward a theoretical argument on the importance of a people-centred approach towards development in mining communities.

2. To contextualise the concepts of CSR and SD within mining communities.

3. To assess the impact of mining operations on the social wellbeing of residents of Welverdiend and the surrounding community.

4. To empirically confirm the importance of a people-centred approach as regards CSR.

5. To make recommendations for developing and improving the wellbeing of communities affected by mining, based on a people-centred approach to development.

\section{Methodology}

In order to accomplish the stated research objectives, information was obtained by means of two main procedures, namely a literature study and a thorough survey.

The literature study, or literature review, focused on the conceptualisation of Corporate Social Responsibility and Sustainable Development, the importance of a people-centred approach for development and the importance of communities for development and CSR. The literature study was also used to contextualise the findings.

In order to ensure the thoroughness of the literature study, the researchers used the following databases:

- The internet, specifically, Google and Google Scholar;

- Journal articles, retrieved from databases such as EBSCO, JSTOR and ScienceDirect as well as from the Ferdinand Postma Library (Potchefstroom Campus);

- Newspaper articles;

- Textbooks; and

- Research studies, conference proceedings and related scientific reports.

The survey was conducted in and around the town of Welverdiend, located in the Gauteng Province of South Africa. Besides the literature study, data were collected during 2011 by using the following data collection techniques: semi-structured interviews, focus-group discussions, key informant discussions and personal observations.

The survey adhered to the qualitative research paradigm. According to Henning (2005:3), qualitative research gives the researcher the chance to understand and explain the phenomena investigated, without any predetermined boundaries, by making use of data and literature. For these mainly inductive enquiry, interviews, focus-group discussions and key informants were used. Neuman (2003:390) states that the field interview is a joint production by the field researcher and research subject. This conversational nature of the interview allows the researcher to explore the participant's experiences, feelings and beliefs. The field research interviews also make space for the mutual sharing of experiences in order to build trust (Neuman, 2003:391).

A focus-group discussion is a special type of interview wherein the participants of the research project get together to converse under the guidance of a supervisor or researcher (Neuman, 2003:396). Such focus-group interviews are of great value, since they create the opportunity for the participants to freely air their opinions, ideas, perceptions and concerns. Patton (2002) describes key informants as participants who are particular knowledgeable about the inquiry setting, who can provide insight in helping the observer understand the situation. 
In order to provide trustworthy findings within the qualitative research paradigm, the research was directed according to and mirrored against the elements as implemented by Cronjé and Chenga (2007:213), and documented in their work. To increase trustworthiness in qualitative research, these authors (Cronjé \& Chenga) specifically dealt with the following four elements in their project (Health Issues in Mining Communities):

- Truth value (confidence in the truth of the findings and the context in which the study was undertaken);

- Applicability (the degree to which the findings can be applied to other contexts and settings, or to other groups);

- Consistency (whether the findings would be consistent if the inquiry was replicated with the same subjects or in a similar context); and

- Neutrality (the degree to which the findings are a function solely of the informants and conditions of research, and not of other biases).

The aim of the questions posed to communities and farmers in interviews and focus groups in line with the Objectives - were two-fold. The first was to determine the social impact of the mines' activities on the communities, considering factors such as the environment and economy. Secondary, the researchers aimed to uncover the participants' views on development and human wellbeing and the importance they hold for CSR. The focus-group discussions as well as semi-structured interviews were used therefore to determine the residents of Welverdiend and the surrounding community's experiences of the mining operations and their impact on their society as well as how development is viewed by the participants. Enquiry into the issues of human wellbeing and development also provided the researchers the link to verify the importance of a people-centred approach in such a setting.

The total study population consisted of approximately twenty-five (25) participants and was selected from the local community, farmers, NGOs, academics, community and environmental activists, and participants from the mining context (managers and mine workers). To congregate the different research subjects, snowball sampling was used. According to Neuman (2003:214), snowball sampling is a method to identify the cases in a network. The research started with an initial group discussion and from that discussion, other contacts, referrals and networks resulted in more appointments. Neuman (2003:214) states that snowball sampling begins with one person or a few people, and spreads out on the basis of links and initial cases, making it a multi-stage technique. One preset condition (for interviewing) was that the participants should be able to express themselves verbally.

During the data collection, the participants chose the research setting, adding to their comfort with the research. Neuman (2003:395) states that a whole interview's meaning is shaped by its gestalt or whole interaction between a researcher and a participant in a specific context.

The qualitative data analysis entailed the recording, transcribing and translating (some of the obtained data was in Afrikaans) of the interviews. The content of the interviews was then analysed by means of thematic (conception) analysis. Neuman (2003:441) indicates that concept formation and theme identification are integral parts of data analysis and the researchers followed that process exactly.

More specifically, the research was directed in accordance with the following eight steps during the process of conceptual analysis, as identified by Palmquist et al. (2005):

1. Deciding on the level of analysis; 
2. Deciding how many concepts to code for;

3. Deciding whether to code for the existence or frequency of a concept;

4. Deciding how to distinguish between the concepts;

5. Developing rules for the coding of texts;

6. Deciding what to do with irrelevant information;

7. Coding texts; and

8. Analysing results.

Consequently, the theoretical argument for a people-centred approach (Objective 1), will be presented.

\section{Central theoretical argument: a people-centred approach}

As stated in the Introduction, the eminent definition of Sustainable Development was defined by the World Commission on Environment and Development (WCED) in 1987. This definition is widely recognised and used world-wide to define Sustainable Development. However, in 2001, the Organisation for Economic Cooperation and Development's (OECD) policy brief defined Sustainable Development, in technical terms, as a

...development path along which the maximisation of human wellbeing for today's generations does not lead to declines in future wellbeing. Attaining this path requires eliminating those negative externalities that are responsible for natural resource depletion and environment degradation. It also requires securing those public goods that are essential for economic development to last, such as those provided by well-functioning ecosystems, a healthy environment and a cohesive society. Sustainable development also stresses the importance of retaining the flexibility to respond to future shocks even when their probability, and the size and location of their effects cannot be assessed with certainty.

Taking a look at the above definition, SD has a sound focus on human welfare. Human welfare, according to the definition, can be achieved and attained in an environment where natural resource depletion and environmental degradation are not visible whilst facing (and achieving) economic goals. Clearly the focus should be on human beings and their welfare for development. In the past, development, in the theoretical sense, was analysed from a macro perspective. More specifically, development was initially framed by the modernisation, dependency and world system theories. Payne and Phillips (2010:56) explain that these development theories developed after World War II in 1945 and were driven by the end of European colonialism, which also led to the creation of new states in Asia and Africa; it was only later that a people-centred approach from the micro level was added.

The micro-foundation of development is based on a people-centred approach. Nayyar and Chang (2005:1) are of the opinion that development should bring about the improvements in the living conditions of people. Basic needs such as shelter, food, health care provision, etc, not only need to be provided, but also the right to live a meaningful life (Coetzee, 2001:119).

The micro-foundation towards development explains that meaningful experiences of reality are the basis of development (Coetzee, 2001:119). Coetzee (2001:120) accentuates that this viewpoint of development differs greatly from the traditional and macro-theoretical theorems. In the past, development was viewed as the result of certain characteristics such as industrialisation, new agricultural techniques, urbanisation, large-scale education and 
specialisation. This view of development, from the angle of modernisation theory, implies that the world is changeable and that people can control the movement from underdevelopment to development by introducing certain characteristics (Coetzee, 2001:120). However, contemporary developmental views indicate that the traditional standpoint of development (especially modernisation theory) lacks insight in the process of change from underdevelopment to development (Coetzee, 2001:120). With regard to the dependency theory, it has been well noted that it is a top-down approach, assuming that the local communities do not have the capacity to oppose their impoverished circumstances (Matunhu, 2011).

Viewed against the above-mentioned critique, the concern here is that the deeper dimensions of underdevelopment are overlooked. This introduces the call for a different view on development entailing the realisation that economic growth and development are not related as such (Coetzee, 2001:122). As early as 1990, the United Nations accentuated the need for a new approach towards development by remarking that its single goal is to put people back in the development process (UNDP, 1990).

The following six principles, as presented by Coetzee (2001:122-126), will serve as the starting point towards a different definition of development, namely the micro-foundation.

\section{People can be more than they are}

Development is based on human wellbeing and can be used as a mechanism for people to become more than they are, through increasing humanness. Increased humanness implies the striving for the following: social justice, comprehensive consultation and joint decision making, the lessening of suffering by satisfying basic needs, respect for the local ecosystem, local social and cultural patterns and the freedom of expression and impression. The striving for increased humanness does not essentially mean an increase in material welfare. Although development projects from the micro perspective also aim to bring material benefits, the main focus is on the increase of human wellbeing.

Meaning

Developmental programmes and plans should stress that progress relies on two factors: the first is on the continuous confirmation of meaning and secondly, progress relies on the will to create a meaningful life. The following are prerequisites for a new interpretation of growth, progress and development:

- A desire among individuals and groups to work towards a specific goal and ideas of reality, the establishment of a political will and general human wellbeing;

- to use existing economic and social structures calculatedly in order to promote individual development; and

- to highlight the distribution of benefits of innovation, knowledge, material investments and general creativity.

The centre of this analysis highlights that meaning and the specific circumstances within which action should take place are most important. With regard to this, a clear understanding of the level of operation is necessary. The following goals give direction regarding how ground-level developmental operations should take place: the provision of a sphere for meaningful existence, community development for social reconstruction, the acknowledgment of social justice, education in the broader sense of the word and the eradication of poverty and inequality. 
The emphasis on the experience of the life-world

As stated previously (Principle One), a development programme or plan accentuating that people can be more than they are does not necessarily entail an increase in material welfare. Instead, development is more likely to succeed when people integrate their life-world meaning into their yearning for developed situations. To incorporate people's life-world meaning, developmental plans are more likely to succeed. People feel they can relate and associate themselves with the programme because it reflects their everyday living or social life-world.

The idea of a total social life-world is strongly associated with the concept of culture (Coetzee, 2001:124). UNESCO's (1995) report, Our Creative Diversity, marks the United Nations' view on culture and its relationship with development. Wright (1998:12) states that the report presents two definitions of culture. The first definition views culture as not just one domain of life, but is 'constructive, constitutive and creative' of all life's aspects, entailing both the economy and development. According to the second definition, the world is made up of separated 'cultures' of people situated within these cultures. The importance of culture for development becomes clear when the report explains that past neglect of people's 'cultures' within the setting of broader 'cultures' has led to the failure of developmental plans (Wright, 1998:12).

Viewed from the micro-perspective, life-world refers to the micro-social reality between individuals. As indicated under the Methodology section (Point 4), the experience of the lifeworld plays a critical role in this research with regard to data collection. Some of the research participants, for example, described in detail their perceived life-world during the interviews and focus groups, which was of course extremely insightful, and essential in order to 'build the research picture' within the setting (also see Findings - Point 7).

\section{Desirable direction}

For desirable direction, meaning and the specific circumstances of where action takes place are at the core of analysis. The departure points of this approach are individual decisions and the processes of interaction, which are related to the process of giving meaning. This implies that it is not a top-down approach but a bottom-up approach. This bottom-up approach stresses that development must be based on human wellbeing, and this should be defined by the people themselves, uncovering their own definition thereof.

\section{Consciousness}

The micro approach towards development is also based on the principle that those who are affected by development must be involved in the development process. This principle is based on the belief that all people have the right to live in a life-world that is meaningful to them. To understand this life-world of people, development should be grounded in the consciousness of people in order to grasp the social reality within which people live. This grounded consciousness implies the existence of a dialogue between society and the individual. This dialectal relationship implies that people have the right to make their own decisions and also have the opportunity to reject any development programme. Therefore, development actions should require the participation of people in the design of any development programme.

\section{Participation and self-reliance}

Participation and self-reliance may be viewed as the two most important aspects of responsible well-being. In the context of development, participation and self-reliance imply 
the necessity to involve the people who are the supposed beneficiaries of development. Participation means doing away with a domination structure, implying that the focus should be at the bottom.

Wellbeing, ranging from spiritual, psychological, social and material human experiences is the ultimate end of development. Chambers (2006:193) coined the term 'responsible wellbeing' and according to him, when wellbeing is qualified by equity and sustainability it becomes responsible wellbeing. Therefore, it can be said that the basics of wellbeing are livelihood, security, equity and sustainability.

Coming out clearly from the discussed principles is that development is for people. People should define their own social reality as well as describe their view of the developmental process.

Taken against the above central theoretical argument, the importance of development and, more specifically, development based on a people-centred approach becomes indispensable for sustainable progress. Furthermore, it has become clear that commitment towards the wellbeing of society holds the key to Sustainable Development. Sriramesh and Verèiè (2009:844) view the role of business in society as follows:

... a company's involvement in communities is not a new phenomenon, what is new however, is a company's commitment towards communities.

This commitment, if true to the triple bottom line, will result in sustainable communities.

The next section will give a detailed account of the relationship that needs to exist between CSR and SD for communities; in this case, the mining community of Welverdiend, in order to achieve sustainable development (Objective 2).

\section{Contextualisation of the concepts CSR and SD within mining communities}

Mining has played, and is still playing an important part in societal development. As Middleton (2003) expresses it, the history of the Stone, Iron and Bronze Ages portrays this. Society's dependence upon mining has not ceased since then; in fact, it has got bigger. Very few products worldwide are not produced from minerals. There are some countries whose economy is totally dependent on the extraction industry. In South Africa, the situation is not any different. According to the Chamber of Mine's Annual Report 2009/10, the mining sector remains a pillar of the South African economy. To illustrate this, the mining sector in South Africa contributes the following: 19\% of the Gross Domestic Product (GDP), about one million jobs, $18 \%$ of gross investment, about $93 \%$ of the country's electricity-generating capacity and about 30\% of the country's liquid fuel supply (Chamber of Mines, 2009/10). Due to the fact that the mining industry fuels job creation, generates electricity supply and adds to the economy of the country, it automatically plays a part in the socio-economic development and welfare of South Africa. The opposite side of the coin: the recent decline and stagnation in the economic growth rate of the country were to a huge extent the result of the continuous strike on the Platinum Belt since the beginning of 2014.

By affecting the social dimension of the country, the mining industries are also capable of promoting a move towards SD. This move is only possible through sound CSR practices. Jenkins and Obara (2008) are of the opinion that for mining companies, CSR is the manifestation of a move towards greater sustainability. The Chamber of Mines (2010) 
reports that the values and aims of sustainable development go hand in hand with the values and aims of the mining industry. Mining companies can achieve progress through the basic dimensions of development, namely: economic development, environmental protection and social cohesion, all three in the course of CSR.

Focusing on the social dimension, a way through which mining companies can achieve progress in SD is by considering the interests of all the stakeholders. Key stakeholders, and ones that are closely tied to the social welfare of the country, are, of course, mining communities (Jenkins \& Obara, 2008).

Not only are communities important because of the impact they have to face from mining, but they also play a critical role in terms of consenting to mining operations. The importance of communities is visible in the authority they have in the process of 'issuing' social rights to mines, granting them approval to mine in an area. These social rights that communities can 'issue' are reflected in what is called a Social Licence to Operate (SLO). Lassonde (2003) defines a social licence as

... the acceptance and belief by society, and specifically our local communities, in the value creation of our activities, such as we are allowed to access and extract mineral resources. ... You don't get your social licence by going to a government ministry and making an application or simply paying a fee. ... It requires far more than money to truly become part of the communities in which you operate.

An SLO gives the mines an opportunity to invest in the local community and, as Nelsen and Scoble (2006) point out, it grants the mines an opportunity to transform and promote the economic and social development of the community, adding to sustainable development.

Veige et al. (2001:192) affirm that the global environment in which mines operate is becoming more and more visible. This global spotlight forces mines to be more socially responsible. In order for mines to be successful in social responsibility action within surrounding communities, the following may be considered (Veige et al., 2001:192):

- Environmental impacts should not present any risk to associated communities;

- Mine development must be perceived to bring a net benefit to the community; to just lessen impacts is not sufficient. Through community diversification that is part of mine planning, development, operation and post-closure, a net benefit would be accomplished; and

- Transparent and effective communication between the mining company and the community is necessary; citizens should be encouraged to share in decisions that directly affect their future. This active participation will help mining companies avoid risks to the sustainability of the mine's operations as well as that of the community.

Operating in accordance with these considerations, mining companies will also function as socially responsible in a given area, and will therefore gain the consent of communities to operate in a specific area. Additional ways to acquire a social licence from communities, as identified by Nelsen (2005), are as follows:

- Understanding culture, language and history;

- Educating local stakeholders about the project, e.g. mining processes and environment impacts;

- Guaranteeing open stakeholder communication;

- Sustaining a sound track record as well as a positive corporate reputation; 
- Training the work-force;

- Creating a business partnership with communities for economic development;

- Employing innovation and technology in order to avoid unnecessary impacts;

- Seeking the support of the community and aiming to build capacity;

- Enabling corporate transparency; and

- Collaborating with communities to answer their infrastructure needs.

The above-mentioned section outlined the importance and inter-relatedness of CSR and SD in mining communities, as well as the critical Social Licence to Operate. Unfortunately, as documented in the findings, mining companies do not always adhere to the prescribed CSR and SD principles, especially regarding the social dimension of development. In doing so, human wellbeing and sustainability will stay a faraway illusion.

\section{Findings}

As discussed earlier in the article (see Point 5) the people-centred approach stresses that human well-being should be the starting point of development and that people should define and voice the experiences of their own social reality. The findings, as obtained through the research, voice the social reality of people living in an area where mining has had, and still has a significant environmental impact. Alongside these social aspects, the participants also discussed their views on CSR and development.

First, the social aspects prevalent in the area, in line with Objective 3, will be put forward.

\subsection{Social Aspects}

From the interviews and focus-group discussions held in the specific community, a number of social aspects were identified and these give an in-depth description of how communities, living in and around Welverdiend, are being affected by mining operations. The broad identified themes were as follows:

- Health

- Hazards

- Livelihood

- Economic wealth versus human wellbeing

- Transparency

- Government

\section{Health}

According to Swart et al. (2003:635), the Wonderfonteinspruit, part of the Far West Rand and found just outside of Welverdiend, was described as a natural jewel during the nineteenth century. Unfortunately, the mining industry did not leave the spruit and its surroundings untouched. The formation of sinkholes, the drop in the groundwater table and even water pollution were some of the mining impacts that affected the spruit and surrounding areas (Swart et al., 2003:635) (see Point 2 - Background on Welverdiend). Supportive of this, a main social issue in the studied community is that of personal health. The participants feel that their health is at risk due to environmental degradation, mainly due to the pollution of water. What is also of concern is that the downstream lying town, Potchefstroom, may also be at 
risk. This is due to the fact that the Wonderfonteinspruit runs into the Mooi River, from where it flows to Boskop Dam, which is the main water supplier for Potchefstroom.

Another critical issue concerning health, which came to the fore during the research, was that of HIV/Aids in the farming community. The concern relates to the poor water quality in the region. It is well known that an HIV sufferer needs a healthy diet (UNAIDS, 2008), and since the farm workers use the contaminated water in their diet, it puts them at a higher health risk.

The following quotations reflect some views of respondents and are reproduced here verbatim.

"We had 6 workers that died of AIDS in the last 6 years, just on this farm; you have the same scenario elsewhere. Give an AIDS sufferer poor food, poor quality water and you have an AIDS accelerator. It is like going for genocide." Farmer

Another water-related problem identified in the area, has to do with farming activities. Numerous farmers stress their concern regarding their land, crops and water use. The following give voice to some concerns in this regard.
"A canal that flows from two upstream mining operations flows into the Wonderfonteinspruit just outside Welverdiend. That may be why the people living downstream of Welverdiend are having more trouble [with farming activities] than those living upstream." Sustainable Development Manager from mine
"I bought some goats years ago outside Carletonville, the grazing is very bad there. And the water is also not suitable for irrigation." Farmer

South Africa is rich in diversity, hosting a variety of different religions and languages. Being a multi-cultural country, respect and conservation towards religious and cultural practices are essential. However, this is not always the case and as Kapelus (2008:280) supportively states, traditional cultural customs are seen as a stumbling block by the mining industry for its activities. The following response from an interviewee clearly portrays the disrespect towards cultural and religious customs in this regard in the Welverdiend area.

\footnotetext{
"Religious groups came to the Gerhard Minnebron to collect water for their sacred ceremonies. A priest wrote a letter to government about his concerns about the quality of the Gerhard Minnebron and their traditions, but didn't get a response." Farmer
}

\section{Hazards}

Geological hazards were identified in the Welverdiend area during the research. A geological hazard can be defined as a threat with the potential to cause harm to people, including death, injury, disease and stress, disruption in human activity, property and the environment (International Strategy of Disaster Reduction, 2010). Two main hazards in the area, according to the interviewees, are that of sinkholes and sinkhole formation.

Apart from environmental problems and land degradation, sinkholes put animals and humans at serious risk. Welverdiend lies adjacent to a mining area and therefore a risk of sinkhole formation exists.

The residents of Welverdiend and surrounding communities have accounted the following with regard to sinkholes. 
"Another problem is that of sinkholes. The Krugersdorp road, which is not far from here [Welverdiend], sank away three to four years ago, because of sinkholes." Resident of Welverdiend

"A few years ago, a sinkhole formed at the town's reservoirs and Welverdiend was without water for some time." Farmer

\section{Livelihood}

Chambers and Conwey (1992:6) propose a working definition of livelihood based on the World Commission on Environment and Management's definition of this concept. According to these authors, livelihood may be defined as follows:

A livelihood comprises the capabilities, assets (including both material and social resources) and activities required for a means of living. A livelihood is sustainable when it can cope with and recover from stresses and shocks; maintain or enhance its capabilities and assets, while not undermining the natural resource base.

The following portrays the risks the community is facing in terms of livelihood and the natural resources they are dependent on:

"We do have calf abortions from time to time, but that can also be due to the fact that we move the cows. We have problems due to the mining operations; we have problems with access control, field fires, erosion as well as cattle theft. Over a 1000 ha burned down, because of field fires recently." Farmer

"Our business is completely closed down. We can't sell the farm, and can't drink the water, but we are not bankrupt, but others are not so lucky... if you lose all your cattle and cannot sell, what do you do, you become like a pensioner sitting in a stingy room eating dog food." Farmer

\section{Economic wealth versus human wellbeing}

The relationship between business and society has been debated extensively over the past decades (see Carrol \& Buchholtz, 2006:4-28; Bakan, 2004:66-168; Hamann, 2008:1-35). A central argument of this discussion is the position a business has to portray in a society; and that the relationship should not foster the one in terms of economic development, and neglect the other in terms of societal and environmental degradation.

The overall view from the participants was that the mines are completely economically orientated. Wealth creation is put at the centre of the mining industry's operations, and in the process, environmental and social problems are created. Therefore, the interviewees feel that economic welfare is mostly generated at the expense of the wellbeing of communities.

The following are views on how the community experiences the mine's position in society.

"I don't believe that the mines show any respect for the eco-system or the people, they do everything for their own benefit...." Resident of Welverdiend

"Sinkholes do happen, and it is because of mining. We [the mine] do what we can in terms of solving the social problems with regard to the formation of sinkholes. Sinkholes cannot be prevented. We [the mine] take responsibility from 1997 when we bought the mine over. Not earlier." Sustainable Development Manager of a mine 
"There are a lot of social and environmental issues because of the mining and the root of the problem is money." Academic

"Since the 20th century, the attitude was: Let's make money. Research shows that the government was also very supportive towards mines." Historian

"It is true, the groundwater table did drop in some places, but it [mining] benefited the country's economy." Mine worker

\section{Transparency}

It was no surprise that the question of transparency was very strongly raised by the research subjects, seeing that ethical and responsible behaviour is supposed to underlie corporate citizenship. Respondents felt that to keep information from them regarding pollution, rehabilitation and economic deals and transactions, is nothing less than a corporate crime. People have, of course, the right to access information, and the issue of free prior and informed consent (FPIC) also comes into play at this point.

The following are views on transparency regarding the essence of this study as seen by the community of Welverdiend.
"Some farmers were bought out by mines. They are not allowed to speak to the public and they are not allowed to make any future health claims." Farmer
"[A mine] is busy building a new tailings dam, but farmers were not considered and the building started suddenly. The dam is over the 400 ha." Resident of Welverdiend

\section{Government}

Historically the National Party, who ruled South Africa from 1948 to 1994, played an essential part in the mining industry. Turton (2008:1) states that an alliance was formed between the government and the gold mines. This alliance entailed that the mines supported the government during the Apartheid era in the country, and when sanctions were put on South Africa, the mines served as an economic safety net. In return, the government allowed the mining companies to make substantial profits by externalising their costs onto society. In this regard, Adler et al. (2007:33) supportively argue that "...the early gold-economy was simply an extractive industry with little consideration given to possibly adverse long-term effects".

The relationship between the current government and the extractive industry is similar to that of the past (Apartheid era). The participants feel that the relationship between these two parties is benefiting both. The government is turning a blind eye to social and environmental issues because of the economic value created by the mining industry and, in return, the mines are granted complete freedom in their operations (harming the environment, mine without water licenses, etc). Political interference and questionable involvement in the sector are also being observed more and more over the last few years. Whilst giving the mining industry full authority, the government is, at the same time, neglecting its own responsibility towards society. Presumably, the government should play a central part in sound CSR practices. It is not merely corporations' responsibility to be socially responsible, but social responsibility stretches beyond corporate borders, also to the government. The United Nations (2010) reports that the role of government in terms of social responsibility is four-fold, namely the regulating, facilitating, warranting and brokering of CSR agendas. 
Derived from the above, it is clear that the government should take an active stance towards social responsibility. Unfortunately, as seen in the findings below, government fails this duty from time to time, for various reasons.

\begin{abstract}
"The big problem is that there are always politics involved in the mining industry." Resident of Welverdiend

"The government wants to make money out of the environmental problem. They get $\mathrm{BEE}$ companies to do rehabilitation work, where we [the mine] can do it for less. The government uses the environmental issues as a whip to get to the mines, because they [the government] don't want to take responsibility." Mine Worker

"Complaints from oppositional parties were documented from as early as the 70s. Stating that the government is polluting the environment and that sinkholes are a problem, and that the people are being affected. But government had another vision. Money talks harder..." Historian
\end{abstract}

Derived from the above findings on relevant social issues in the area, it is obvious that the mining industry has not left the residents of Welverdiend and the surrounding community untouched. It is against these negative social findings that the position of development becomes uncertain. The people-centred approach insists that development can only be defined by those living in an underdeveloped situation (see Point 5). In accordance with this, the following findings display how development is viewed by the research participants (Objective 4).

\title{
7.2 Views on Development in support of the People-Centred Approach
}

As acknowledged (see Point 6), CSR and SD are inseparable. Sound CSR actions by corporations will foster SD, making CSR a perfect fit for SD and vice versa. When referring to the social wellbeing of people, the social dimension comes strongly to the fore; development is for people.

Derived from the above-mentioned, a developmental approach with a strong people focus seems like the ideal approach for sound CSR practices. As already mentioned, such an approach is the micro-foundation towards development, also known as the people-centred approach (see Point 5). People thus form the essence of this developmental approach; therefore, it is appropriate to take note of the opinions of different people on these important issues.

It must also be noted that the evaluation in this study of the importance of the peoplecentred approach within the framework of CSR and development rests on the perceptions of the study population. The findings, as obtained from the interviewees, will consequently be presented. The following quote hints towards the educational role of corporations.
"The power of a corporate institution can also educate people. There should not only be looked at how the people are affected, but [corporations] should accommodate and educate people to become environmental conscious. Corporations should invest in the living spaces of the people. Corporations have enormous power in their operating space to educate its employees." Academic

In line with the micro-foundation towards development, people should form the basis of any development programme. The following quotes by some of the participants display the 
importance of people in the development process and the change that is needed in the mindsets of people for CSR to be successful.

"People are the basis of any development. Macro development is driven by the government and one could question their competence. Poverty is the biggest problem, because we cannot get enough people in the system so that they can have a job. When you have a job, you also become disciplined and develop thereafter. Social grants are a big problem, because we are creating a back log and the pressure on society is getting bigger and bigger." Mine Worker

"We [people] have a mindset on how the environment may be used and abused; CSR needs to change that, a mind shift needs to be concluded. With CSR, there is definitely a change for the better compared to when there was no such structure, but we still have the baggage of wrong thinking and an environment that is shattered." Historian

"There needs to be a change of framework and a move towards a socialcapitalistic system. In the past there was not something like Sustainable Development or CSR; now that it is getting to be more in the foreground, some change for the better is taking place, but we sit with problems because of the neglect of CSR in the past. The focus was on the economy." Mine worker

"You have to go back to the basics. In society there are certain risks; societal risks, and in South Africa, what are the big things? Poverty, unemployment and crime. All those are linked. And when you have a business considering development you need to take into account the impact of your development, and that it should be positive. Yes, we as Goldfields go into a community and put up a casino, some people might go and work there, but what are you doing actually? Degrading the moral fibre, so you need to take that into account. Based on what I just said, one thing that holds us back as a country is education. So you need to tap into that: building of schools, getting better education, so we have kids coming out that are engineers, scientists, etc. That is the baseline. When you are dealing with our illiteracy rate, you are dealing with a set of people, although there are jobs out there, they don't fill them because they don't have the skills. They don't have the basics to get the skills. So development starts with building capacity and it starts with education. The second part that ties in with that is health. If the community is literate and unhealthy, that doesn't help either. So we focus on getting the baseline right. The other aspect with poverty is hunger. So we need to develop our agriculture; it is important for development. So when we do projects, we focus on education, health and agriculture.” Mine Manager

When looking at the above-mentioned findings, it is clear that the underlying golden thread to a people-centred approach boils down to business ethics. Business ethics is concerned with the behaviours of individuals in a business as well as in the broader society (Blowfield \& Murray, 2008:18). The challenge is clearly to integrate business ethics and other core values, such as respect, honesty, trust and fairness into the day-to-day practices of the company; thus striving towards the business case for CSR. Taken against the findings that have been discussed so far in the article, business ethics in the mining industry is not that easily accomplished and the following quote, coming from a mine manager, captured the essence perfectly of how CSR should be conducted. 
"Ultimately, I would like to see that Sustainable Development should totally disappear, because Sustainable Development is the way you do business. So when people do things, they should think automatically how it is going to be better for the environment and development.” Sustainable Development Manager from mine

To conclude, the following quote by a participant sums up the importance of a peoplecentred approach for sustainable development:

"People are the building blocks of society and wellbeing is the most important thing. Not only physical wellbeing, but also psychological wellbeing. If we don't get development right, the real losers are the next generation." Farmer

Derived from the findings of the study and viewpoints of the respondents, personal observations by the researchers, basic concepts related to the theoretical argument, as well as some relevant suggestions from the literature, the following general recommendations (Objective 5) can provide mining companies with some direction towards sound CSR practices, especially with surrounding communities in view.

\section{RECOMMENDATIONS}

- Education should be placed at the centre of a company's CSR programmes. The focus here is on the building of human capital. In terms of education, the whole spectrum can be considered by a company for possible involvement and support, i.e. from ABET (Adult Basic Education and Training), primary and secondary schooling (building of schools, special education programmes for children in this educational range, etc) and bursaries and internships for learners who finish school. By fostering human wellbeing through education, the social development of South Africa will be positively influenced.

- Given the socio-economic context of South Africa, poverty eradication should form an integral part of any mining company's CSR agenda. This could be achieved through the difficult and contentious process of employment creation, directly by sourcing jobs from the neighbouring communities, but also indirectly through the provision of portable skills through training programmes and the establishing and strengthening of a talent pool in communities. Job creation will also be the foundation for other facets of human development, such as individual growth, selfreliance and self-actualisation. These human resource development initiatives are, anyway, implied by the Social and Labour Plans (SLPs) that mining companies must submit to the Department of Mineral Resources (DMR) and required by legislation (Section 100 of the Mineral and Petroleum Resources Development Act, 2004).

- Economic growth, social development and environmental protection should be incorporated and synchronised (Triple Bottom Line) within a company's CSR programme and developmental agenda, and also be managed in a real, sustainable manner. Local economic development (LED) is also one of the 'departments' that needs to be addressed by the SLPs of mining companies. Developmental projects must be established in local communities in line with needs and priorities indicated by Integrated Development Plans (IDPs) and Local Economic Development Plans (LEDPs) of local governments. In this regard, proper consultation and the issue of free, prior, and informed consent (FPIC) with communities must be the starting 
point of any potential project. In terms of the sustainability regarding these issues, provision and a plan for mine closure are another very important aspect (also required by the Social and Labour Plan); a prerequisite that is definitely not adhered to in the context of Welverdiend and its people. The same applies, of course, to environmental responsibility; policies stipulated by (hopefully!) approved Environmental Impact Assessments (EIAs) and practice on the ground are two different 'things', as are seen in Welverdiend.

- Proper engagement with and consent of the community (FPIC) are crucial to the success of mining activities, CSR programmes and policies, and ultimately, sustainable development (see 7.1). When companies are serious regarding the 'requirements' of the Social License to Operate (SLO) in an area, CSR practices will be developed that will probably respond to the need(s) that exist in a community, adding to the welfare of people.

- Transparency should form a fundamental part of a mining company's CSR practice. Public and community members have the right to be informed of any impact, negative or positive. By having access to information, communities have the privilege to make informed decisions in terms of their personal wellbeing and development in a wider context.

- People's livelihood should, by all means, be safeguarded instead of being destroyed or negatively impacted on by the mines. Poverty and unemployment are critical social issues in South Africa; therefore, CSR practices and programmes should be aimed at the protection of people's livelihoods.

- Together with the private sector (e.g. mining companies), the government's role in terms of development should be defined. Social responsibility is not just the responsibility of mining companies, the government, too, should play an integral part in overseeing the implementation of the regulatory frameworks. The Mineral and Petroleum Resources Development Act (MPRA - 2002/2004) and the Broad-based Socio-economic Charter for the Mining Industry (The Mining Charter, 2002 \& 2010) have a clear focus on people and development; it is therefore the government's responsibility to ensure compliance with these frameworks by the industry.

Through the research it has been found that the communities in and around Welverdiend are faced with certain social issues due to poor CSR practices. These social aspects may not only be attributed to the current mines operating in the area, but can also be traced back to former mining companies. Through the exploration of the community's people, mine employees as well as academics' views on CSR, it has become clear that a people-centred approach towards development is the answer to sound CSR practices and sustainable development. However, a mind change or change of framework needs to take place. This approach will not only lead to development but will also, most importantly, minimise the social issues that communities have to face due to a lack of proper CSR actions. The last section (Conclusion) discusses the change of framework that needs to take place in order for a people-centred approach to fit into the CSR practices of a company.

\section{CONCLUSION}

In light of the findings (see Point 7), sound CSR practices from companies and responsible governments turned out to be the most important answer for a community like Welverdiend. Unfortunately, some of the mining operations and origins of accompanying consequences could be dated back to more than seventy years. The question about who is literally going to 
take responsibility can thus rightly be asked. Opinions and visions from mining companies currently in operation in the area seem hopeful; however, policy and practice are two different concepts. The Welverdiend situation reflects much similarity with the contentious situation found on the South African West Coast, where De Beers drastically scaled down its operations at Kleinzee and left most communities in dire straits (see Cronjé et al., 2009). The result regarding this study is that residents and surrounding communities in the Welverdiend area are at the receiving end of irresponsible corporate actions (past and present) and in a state of despair. In worst-case scenarios, even basic human health is at risk. Based on this, it is hard to imagine that such a community would be in the position to grow and develop.

Regarding these implied issues and aligned with the article's objectives (see Point 3 ), the views of the study population on a human-centred approach, CSR practices and development can be summarised as follows:

According to the participants, the wellbeing of people forms the basis of development. Most importantly, it has been found in this study that a change in the mindsets of people is necessary for sound CSR practices. This change is needed in order to protect and develop human wellbeing through sound CSR practices. It has been mentioned in some of the focus groups that the investment in people is crucial for development; this investment should mostly aim at education in the broad sense of the word, involving literacy to basic labour skills (also see Recommendations), which will also lead to the eradication of poverty.

The lack of acknowledgement of communities by companies is really a sad state of affairs; even the World Bank iterates this important dimension. The World Bank described CSR as

...the commitment that businesses have to contribute to sustainable economic development, working with employees, their families, the local community and society at large to improve the quality of life, in ways that are both good for business and development (Blowfield, 2005:515).

Unfortunately, in light of the findings of this research, it is evident that economic wealth is favoured over human wellbeing, making it the root cause of the social issues identified. Respondents were of the opinion that the ruling 'capitalist nature' is posing a test for sound CSR practises. As previously stated, a change of framework needs to take place for sound CSR practices; unfortunately capitalism serves as a great challenge for this shift of framework to take place. Blowfield (2005:520) supportively argues that the greatest challenge and limitations for CSR are related to the fundamental values and beliefs of the capitalist enterprise. A capitalist enterprise involves the right to make profit, free trade, the freedom of capital, the supremacy of private property, the commoditisation of all sorts of things including labour, the domination of market in the determining of price and value and the privilege of companies to act as citizens and moral entities (Blowfield, 2005:520). These capitalist notions are not new, and are documented in the work of Adam Smith, Karl Marx, John Maynard Keynes and Milton Friedman, to mention a few. A farmer expressed the view that "people are nothing for the mine, only a number. The mine is only there to make money". This viewpoint corresponds with the famous statement made by Friedman, namely that "...there is one, and only one social responsibility for business - to use its resources and engage in activities designed to increase profits" (Friedman, 1970:6). The aim at this point is not to argue the importance of CSR; this has been done throughout the research article and is also evident from the findings. An important focus to be stressed here is rather the milieu in which CSR is taking place, i.e. capitalism, and the fact that a change of framework is needed for CSR to result in sustainable development. Against this reality, Nayyar and Chang (2005:2) 
recognised this leading ideology of economic wealth creation, and respond by identifying the following three points of departure for development:

- The first point of departure states that the wellbeing of humankind serves as the essence of development. According to Nayyar and Chang (2005:3), this point tends to be forgotten because of the dominant discourse, where 'economic freedom' gets more attention than individual well-being;

- The second point states that a distinction between the means and ends should be established. Economic growth and efficiency are means while economic development and social progress are ends (Nayyar \& Chang, 2005:3); and

- The third point stipulates that economic growth is necessary but not sufficient in the eradication of poverty. The outcomes of economic policies should not be moderated by social policies. The dichotomy between economic and social development is inadequate, so is the dichotomy between economic and social policies (Nayyar \& Chang, 2005:3).

Against these points of departure, Nayyar and Chang (2005:3) conclude that a need for integrative social and economic policies exists, and that it is time to explore alternatives in development. Examining the above three focus points, it is clear that human wellbeing and society play an essential part in development. These points of departure are, of course, also entwined with the people-centred approach for development (see Point 5). Such an argument marks the micro approach not only as an essential approach for development, but also as the most important approach for development in terms of sound CSR practices.

\section{BIBLIOGRAPHY}

ADLER, RA, CLAASSEN, M, GODFREY, L \& TURTON, AR 2007. Water, mining, and waste: An historical and economic perspective on conflict management in South Africa. The economics of peace and security journal, 2(2):33-41.

BAKAN, J 2004. The Corporation. London: Constable \& Robinson.

BEZUIDENHOUT, A, FIG, D, HAMANN, R \& OMAR, R 2007. Political Economy. (In Fig, D, ed. Staking Their Claims: corporate social and environmental responsibility in South Africa. Pietermaritzburg: University of Kwa-Zulu Natal Press. pp 13-94).

BLOWFIELD, M 2005. Corporate Social Responsibility: International Affairs, 3:515-524.

BLOWFIELD, M \& MURRAY, A 2008. Corporate Responsibility: A critical introduction. Oxford: Oxford University Press.

CALLINICOS, L 2007. Die verhaal van goud [The tale of gold]. (In Giliomee, H \& Mbenga, B, eds. Nuwe Geskiedenis van Suid-Afrika. Kaapstad: Tafelberg. pp 199113).

CARROLL, AB \& BUCHHOLTZ, AK 2006. Business and Society. Ethics and stakeholder management. Mason: Thomson.

CHAMBERS, R 2006. Transforming Power: From Zero-Sum to Win-Win, IDS Bulletin 37(6):99-110. 
CHAMBERS, R \& CONWAY, GR 1992. Sustainable rural-livelihoods: practical concepts for the 21st century. IDS Discussion paper 126. http://opendocs.ids.ac.uk/opendocs/bitstream/handle/123456789/775/Dp296.pd??seq uence=1 Date of access: 30 Aug 2011.

CHAMBER OF MINES OF SOUTH AFRICA. 2010. Annual Report. http://www.bullion.org.za/documents/AR\%202010\%20small.pdf Date of access: 4 Aug 2011.

COETZEE, JK 2001. Micro Foundation for development thinking. (In Coetzee, JK, Graaff, J, Hendricks, F \& Wood, G, eds. Development: theory, policy, and practices. Cape Town: Oxford University Press. pp 118-139).

COETZEE, H, WINDE, F \& WADE, PW 2006. An assessment of sources, pathways, mechanisms and risks of current and potential future pollution of water and sediment in gold-mining areas of the Wonderfonteinspruit catchement: WRC REPORT $1214 / 06$.

http://www.wrc.org.za/Knowledge\%20Hub\%20Documents/Research\%20Reports/12 14-1-06.pdf Date of access: 30 June 2011.

CRONJÉ, JF \& CHENGA, CS 2007. Health Issues in the mining community in South Africa. (In Falola, T \& Heaton, MM, eds. HIV/Aids, Illness, and African Wellbeing. Rochester, NY: University of Rochester Press. pp 210-242).

CRONJÉ, JF, VAN WYK, D \& VAN WYK, LJ 2009. SADC Research: Corporate Social Responsibility in the Diamond Mining Industry on the West Coast of South Africa. Research done on behalf of the Netherlands Institute for Southern Africa (NIZA) and the Bench Marks Foundation. Johannesburg, South Africa. 88 p.

FRIEDMAN, M 1970. The Social Responsibility of Business is to Increase its Profits. http://www.umich.edu/ thecore/doc/Friedman.pdf Date of access: 19 Aug 2011.

HAMANN, R 2008. Introducing corporate citizenship. (In Hamann, R, Woolman, S \& Sprague, C, eds. The Business of Sustainable Development in Africa. Pretoria: Unisa Press. pp 1-35.)

HENNING, E 2005. Finding your way in qualitative research. Pretoria: Van Schaik Publishers.

ISSD (International Institute for Sustainable Development) 2010. ISO 26000 (CSR Guidance). http://www.iisd.org/ Date of access: 12 Aug 2010.

JENKINS, HM \& OBARA, LJ 2006. Corporate social responsibility in the mining industry - the risk of community dependency. http://www.crrconference.org/downloads/2006jenkinsobara.pdf Date of access: 11 July 2011.

KAPELUS, P 2002. Mining, Corporate Social Responsibility and the "Community": The Case of Rio Tinto, Richards Bay Minerals and the Mbonambi. Journal of Business Ethics, 39:275-296.

LASSONDE, P 2003. How to earn your Social Licence. Mining Review, 7-13.

LIEFFERINK, M 2009. Environmental Impact Assessment: Rand Uranium Proposed Reprocessing of Tailings for Gold and Uranium Extraction in the Randfontein/Westonaria Region. 
MATUNHU, J 2011. A critique of Modernisation and Dependency theories in Africa: critical assessment. African journal of History and Culture, 3(5):65-72.

MIDDLETON, N 2003. The global casino: An introduction to environmental issues. New York: Hodder Arnold.

NAICKER, K, CUKROWSKA, F \& McCARTHY, TS 2002. Acid mine drainage arising from gold mining activity in Johannesburg, South Africa and environs. Journal for Environmental Pollution, 211:29-40, July.

NAYYAR, D \& CHANG, H 2005. Toward a people-centred approach to development. (In Hershberg, E \& Thornton, C, eds. The Development Imperative: Toward a PeopleCentered Approach. New York: Social Science Research Council. http://www.ssrc.org/workspace/images/crm/new_publication_3/\%7Bb6cac51c-f246de11-afac-001cc477ec70\%7D.pdf Date of access: 3 Apr 2011.

NELSEN, J 2005. Social License to Operate Survey. http://www.mining.ubc.ca/files/SLO\%20CIM\%20LW.pdf Date of access: 5 May 2008.

NEUMAN, LW 2003. Social Research Methods. Boston: Allyn and Bacon.

ORGANISATION FOR ECONOMIC COOPERATION AND DEVELOPMENT 2001. Policy brief Sustainable Development: Critical Issues. http://www.bloomberg.com/news/2010-11-15/aurora-run-by-zuma-mandela-familyowes-miners-pay-update1-.html Date of access: 11 July 2011.

PALMQUIST, M, BUSCH, C, DE MARET, PS, FLYNN, T, KELLUM, R, LE, S, MEYERS, B, SAUNDERS, M \& WHITE, R 2005. Content analysis. Writing@CSU. Colorado State University Department of English. http://writing.colostate.edu/references/research/content/ Date of access: 30 June 2007.

PATTON, MQ 2002. Qualitative research \& evaluation methods (3rd ed). Thousand Oaks, CA: Sage.

PAYNE, A \& PHILLIPS, N 2010. Development. Cambridge: Polity Press.

SRIRAMESH, K \& VERCIC, D 2009. The Global Public Relations Handbook: Theory research and practice. Routledge: Oxon.

STOCH, EJ 2014. Mining in the Welverdiend area. [Telephonic Interview - Liefferink, M.] May, Johannesburg.

SWART, CJU, STOCH, EJ, VAN JAARSVELD, CF \& BRINK, ABA 2003. The Lower Wonderfontein Spruit: An exposé. Environmental Geology, 43:635-653.

THE EUROPEAN COMMISSION. 2002. Social Agenda: Companies face their social responsibilities in Europe abroad. http://ec.europa.eu/social/main.isp?catld=737\&langld=en\&publd=252\&type=1\&furth erPubs Date of access: 25 June 2011.

TURTON, A 2008. Project Concept Note: Tooth Fairy project. http://www.anthonyturton.com/admin/my_documents/my_files/Project_Concept_N ote_version_2.p Date of access: 6 Aug 2011. 
UNITED NATIONS 1990. Human Development Report. http://hdr.undp.org/en/media/hdr_1990_en_overview.pdf Date of Access: 25 Oct 2012.

UNITED NATIONS 2010. Creating Business and Social Value: The Asian Way To Integrate CSR Into Business Strategies. http://www.unescap.org/tid/publication/indpub2565.pdf Date of access: 4 Sept 2011.

VAN EEDEN, ES 2006. Some human actions in the destruction and construction of culture and nature - the Merafong region as a case study. Journal for Trans-disciplinary Research in Southern Africa, 2(2):409-430, Dec.

VAN EEDEN, ES 2007. An historical assessment of NGO efficiency in progressing towards a sustainable environmental heritage focus, with as case study the Wonderfontein Spruit catchment, Gauteng. http://www.pea.org.za/latestnews/upload/news_doc_78.pdf Date of access: 28 June 2011.

VAN EEDEN, ES, LIEFFERINK, M \& TEMPELHOFF, E 2008. Environmental ethics and crime in the water affairs of the Wonderfontein Spruit Catchment, Gauteng, South Africa. Journal for Transdisciplinary Research in Southern Africa, 4(1):31-58, July.

VAN EEDEN, ES, LIEFFERINK, M \& DURAND, JF 2009. Legal issues concerning mine closure and social responsibility on the West Rand. Journal for Transdisciplinary Research in Southern Africa, 5(1): 51-7, July.

VAN NIEKERK, HJ \& VAN DER WALT, IJ 2006. Dewatering of The Far West Rand Dolomitic Area By Gold Mining Activities And Subsequent Ground Instability: Land degradation and Development, 17(4):441-452.

VEIGE, MM, SCOBLE, M \& MCALLISTER, ML 2001. Mining with communities. Natural Research Forum, 25:191-202.

WARHURST, A 1998. Corporate social responsibility and the mining industry. Presentation to Euromines. Brussels, June 4. http://www.dlist.org/sites/default/files/doclib/Corporate\%20Social\%20Responsibility \%20and\%20the\%20Mining\%20Industry.pdf Date of access: 19 May 2011.

WINDE, F \& STOCH, EJ 2010. Threats and opportunities for post-closure development in dolomitic gold mining areas of the West Rand and Far West Rand (South Africa) - a hydraulic view Part 1: Mining legacy and future threats. Journal of Water SA, 36(1):6974, Jan.

WORLD COMMISSION ON ENVIRONMENT AND DEVELOPMENT (WCED) 1987. Our Common Future. New York: Oxford University Press.

WRIGHT, S 1998. The Politicization of culture? Anthropology Today, 14(1):7-15. 